\title{
Ayurvedic Management of Lagophthalmos - A Case Report
}

\author{
Dr. Chandana $\mathbf{P}^{1}$, Dr. Gururaj Anil Bhat ${ }^{2}$, Dr. Ashwini $\mathbf{M ~ J}^{3}$ \\ ${ }^{1}$ PG Scholar, ${ }^{2}$ Assistant Professor, ${ }^{3}$ Professor and HOD \\ Department of ShalakyaTantra, SDM College of Ayurveda and Hospital, \\ Hassan, Karnataka, India
}

\begin{abstract}
Lagophthalmos condition is characterised by inability to voluntarily close the eyelids 1 . The lesion could be direct trauma to orbicular is, Bell's palsy or infranuclear seventh nerve palsy2. When condition is untreated it may lead to conjuctival and corneal xerosis and exposure keratitis. The treatment is that of exposure keratopathy, the frequent use of tear substitutes and surgical tarsorrhapy is the only line of treatment in modern science3. Ayurveda has given different line of treatment; the present article is a case report of a male patient aged 29 years whovisited eye OPD with complaints of inability to close the right eye since one anda half month associated with itching, watering and burning sensation of eyes. The case was managed effectively withamapachana (morbid factor digestion), seka (sudation), netra abhyanga (local massage of eyes) followed by
\end{abstract} shastikashalipindasweda (sudation) to both eyes and Sadhyovirechana (medicated purgation), Mukha Abhyanga (facial massage) followed by nasya (instillation of nasal drops) orally managed with Astavarga kashaya, Bruhat vata chinthamani rasa and Medhya vati. This study aimed at ayurvedic management of lagophthalmos. Lagophthalmos is vataja condition and the treatment principles mainly focused on mitigation vitiated vata to improve the functioning of eye lid.

Keywords: Lagophthalmos, Vatahata Vartma, Seka and Nasya.

\section{INTRODUCTION}

Eyes are placed in a prime position among the sense organs naturally because of its prominent significance in day to day activities ${ }^{4}$. Eyelids are mobile tissue curtains placed in front of the eyeballs. These act as shutters protecting the eyes from injuries and excessive light. These also perform an important function of spreading the tear film over the cornea and conjunctiva and also help in drainage of tears by lacrimal pump system ${ }^{5}$. Lagophthalmos is a condition in which there is incomplete closure of the palpebral aperture when an attempt is made to close the eyes. It can be uniocular or binocular. It may be due to contraction of the lids from cicatrisation or a congenital deformity, ectropion, paralysis of the orbicularis, proptosis or laxity of tissues and absence of reflex blinking ${ }^{7}$. When condition is untreated, it may lead to conjuctival and corneal xerosis and exposure keratitis. The treatment is that of exposure keratopathy, the frequent use of tear substitutes and surgical tarsorrhapy ${ }^{8}$.

The above presented disease can be compared with vatahata vartma in ayurveda. It is described under vartmagata netra roga, it is vata dosha dominant disease ${ }^{10}$. According to Acharyasusrutha the signs and symptoms are vimuktasandhinishchesht(loss of integral function of eye lid), nameelyathe(unable to close eyelid) and it may be painful or painless ${ }^{11}$. As per the classical texts, the prognosis of the disease is not so positively promising, howeverdetoxification, systemic and local therapies which strengthen muscles, nerves and reduce vitiated vata can produce improvement in the condition. In the present case, the vatahara line of treatment, oleation, sudation and muscle strengthening procedures and orally,Astavarga kashaya, Bruhat vata chinthamani rasa and Medhya vati were administered to pacify the vitiated vata dosha.

\section{Consent:}

Informed consent was taken prior to case study. 


\section{Case report:-}

A 29 years male patient residing in Arkalgudu, Hassan district visited the Eye opd of Sri Dharmasthala Manjunatheshwara College of Ayurveda and Hospital, Hassan on complaining of inability to close the right eyelid since one and a half month associated with itching, watering and burning sensation of eye. Patient was asymptomatic till he met with a road traffic accident and got injury to the right temporal and mandibular region. Since then patient complaints of inability to close the right eye associated with watering of right eye, itching, pricking type of pain in the right eye lid. For above said complaints he was admitted in SDM College of Ayurveda and Hospital, Hassan for further management. There was no history of diabetes mellitus or hypertension. His vitals were within normal limits. On general examination, there was no pallor, icterus, clubbing of nails, oedema or lymphadenopathy. CNS examination revealed theparalysis of orbicularis oculi muscle.

\section{Investigations-}

Routine haematological and urine investigations were carried out and findings were not of any pathological significance.

\section{Local Examination:-}

Head posture was normalwithhead placed in straight and erect posture.Facial symmetry present with eyebrows and eyelid of both the eyes placed at same level. Ocular posture was normal, visual axes of two eyes are parallel to each other in primary position and is maintained in all position of gaze.

On eyelid examination, position of both the eyelidsin the affected and non-affected eyes were upper eyelid covered 1/6th of the cornea and lower lid touched the limbus. The upper eyelashes of the affected and nonaffected eye were directed forwards, upwards and backwards. On examination of movements of eyes in right eye, patient was unable to close the eye, left eye normal with normal movements. Similarly, the lower eye lashes were directed forwards, downwards and backwards. There was no visible trichiasis and poliosis.

On examination, lacrimal apparatus appears to be normal, skin over lacrimal sac- redness and swelling absent. On eye ball examination, the condition of proptosis and exophthalmos wereabsent, uniocular and binocular movements were possible. On conjunctivalexamination revealed absence of congestion, chemosis, discolouration, follicles, papillae, pterigium and pingeculae in both the eyes. The sclera was white in colour and covered by bulbar conjunctiva in both eyes. On corneal examination, the size, shape, surface and transparency was normal. On anterior chamber examination by normal torch light method, the iris showed presence of crypts, ridges and collaretes. The pupil was normal on examination in both the eyes with normal pupillary reflex.

The visual acuity before treatments of both eyes were $6 / 6$, of right eye was $6 / 6$ and in the left eye $6 / 6$ was observed before and after treatment.

\section{Treatment protocol}

On first day, patient was given amapachanna with chitrakadivati in the dose of 2 tablets tid followed by kriyakalpa procedures like Seka with bala and rasna kashaya, Netra abhyanga with ksheerabala 101 drops followed by ShastikaShaliPindaSweda to both eyes. On the second day of the treatment Sadhyovireachana with GandharvaHastaditaila $60 \mathrm{ml}$ was given on empty stomach and patient had four Vegas.On third day,Mukha Abhyanga with Asanabilvaditaila followed by Marsha nasya with Ksheerabalataila101 avarti, 10-10 dropsto each nostril in the morning on empty stomach andSeka with bala and rasna kashaya, netra abhyanga with ksheerabalaavartifollowed by shastikashalipindaswedawere advocated in the afternoon for 7 days. Internally, patient was prescribed with Astavarga kashaya,Tablet Bruhat vata chinthamani rasa 1 bid andTablet Medhya vati 2 tid.

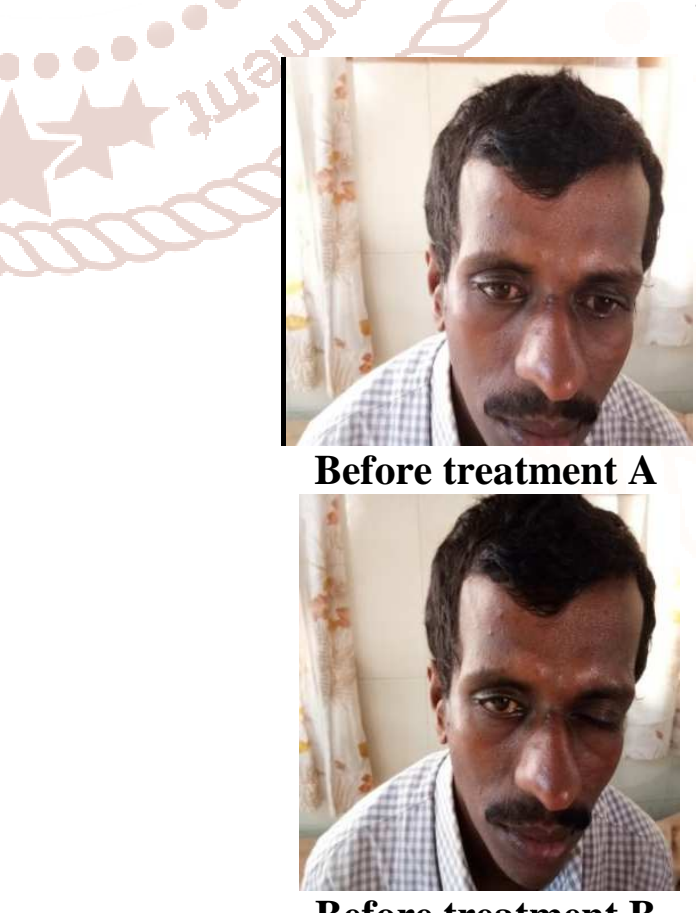

Before treatment B 


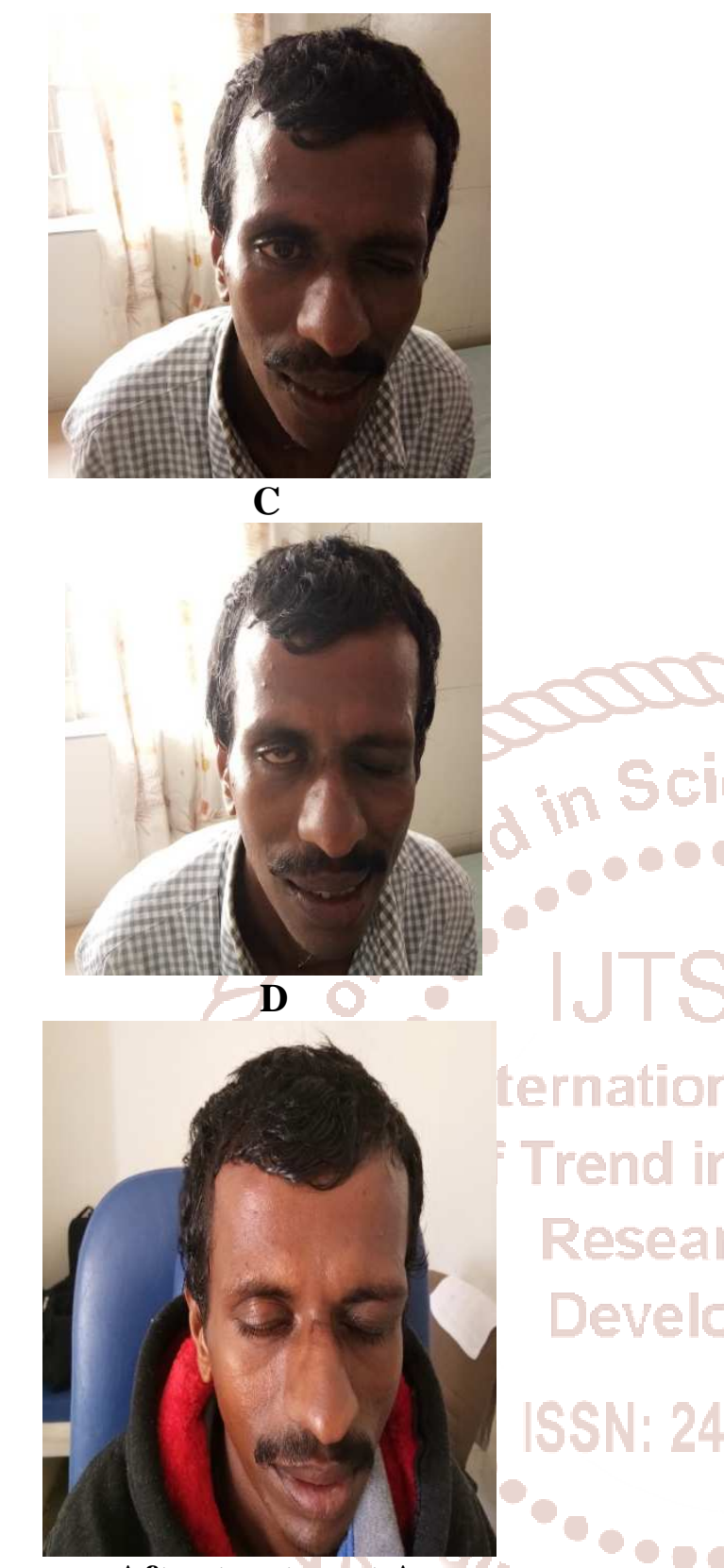

After treatment A

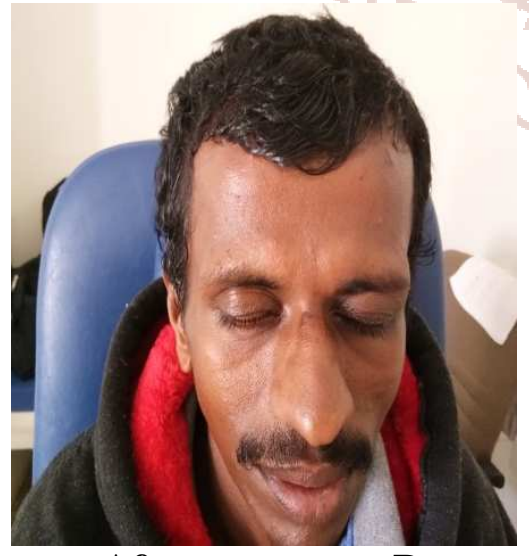

After treatment B

Results: - Significant changes in signs and symptoms were noticed in before treatment and after treatment with short course of 7 days. On first day, patient was unable to close the right eye associated with itching, watering and burning sensation of eye. Later, on third day, itching, watering of eye reduced to $50 \%$ and on day $7^{\text {th }}$ day, complaints ofitching, watering subsided completely and was able to close voluntarily the right eye lid completely.

\section{Discussion:-}

Lagophthalmos condition is characterised by inability to voluntarily close the eyelids. It may be due to contraction of the lids from cicatrisation or a congenital deformity, ectropion, paralysis of the orbicularis, proptosis or laxity of tissues and absence of reflex blinking. When condition is untreated, it may lead to conjuctival and corneal xerosis and exposure keratitis. In Ayurveda, it can be correlated to vatahata vartma. It is one among the vartmagata netra roga and categorized under asadhyavyadhi(poor prognosis category of diseases). But owing to the fact that the patient cannot be denied treatment; considering the prognosis, physician should provide every possible effort to improve the condition. Although results are not so positively promising but the improvement in presenting complaint can be achieved with ancient classical therapies.In the above condition, vata was vitiated due to abhigata (injury). Hence,sadhyovirechana which was administered with the help of GandharvaHasthadithailadetoxifies the body. Nasya karma, the procedure of instilling medications in the form of nasal drops is believed to strengthen the muscles and nerves of sense organs.Ksheerabala oil processed 101 times, when administered through nasal instillation, is expected to strengthen the vital functions of the sense organ by its unique mode of action through shringhatakamarma (vital point - cavernous sinus?). Seka, the external ocular therapy wherein the medicaments are poured in the form of minute stream over the closed eyes for a prescribed time period was administered with decoction of bala and rasnawhich areexpected to mitigate vata dosha present in the local area. Netra abhyanga, the therapeutic gentle eye massage, helps to produce desired oleatory effect in the lid. The oil selected for the eye massage will stimulate and strengthen the lid muscle. After proper oleation, mild sudation is administered with help of shashtikashali (rice grown in 60 days), which is boiled in milk. Shashtikashaali when boiled in milk attains the nourishing quality. The combination of oleation and sudation helps to restore the function of lid. The ingredients ofAshtavargaKashaya help to reduce the vitiated vata systemically. Bruhat vata chinthamani rasa,a specially designed formulation helps to win 
over the vitiated vata and restore the function of sense organ. The rasayana prescribed helps to maintain the improvement and enhances the function of eye.

\section{Conclusion:-}

Lagophthalmos condition is characterised by inability to voluntarily close the eyelids. The lesion could be direct trauma to orbicularis, Bell's palsy or infra nuclear seventh nerve palsy. The signs and symptoms of lagophthalmos can be correlated with vatahata vartma according to Ayurveda and is categorised under vartmagataasadhyarogas. Efforts were done to improve the quality of functioning of eye lid. AcharyaSusruta, advocated that the dominant dosha involved is vata and the clinical features of this condition are same as that of lagopthalmos. The line of treatment followed in this condition were oleation, sudation, nasya and other locally advocated therapies were mainly vatahara, strengthening and nourishing in nature. Patient was provided with satisfactory result in this case.

\section{References:}

1. Khurana. A. K. Comprehensive ophthalmology. 4thedition. New delhi; New age international, 2007; pg. 355

2. Mukherjee $\mathrm{P} \mathrm{K}$. Clinical examination in ophthalmology. $2^{\text {nd }}$ edition. Haryana; Elsevier; 2016; 72

3. Parsons' diseases of the eye. sihotaramanjit, tendon rhadika. $22^{\text {nd }}$ edition. Haryana; Elsevier, 2011; pg.460
4. Naryan J Vidwansa. A textbook of ayurvedic ophthalmology. shalakya $1 ; 4^{\text {th }}$ edition Pune ;Vimal vision publication, 2015

5. Khurana. A .K. Comprehensive ophthalmology. $4^{\text {th }}$ edition. New delhi; New age international, 2007; pg.355

6. Mukherjee $\mathrm{P}$ K. Clinical examination in ophthalmology. $2^{\text {nd }}$ edition. Haryana; Elsevier; 2016; 72

7. Parsons' diseases of the eye. sihotaramanjit, tendon rhadika. $22^{\text {nd }}$ edition. Haryana; Elsevier, 2011; pg.460

8. Parsons' diseases of the eye. sihotaramanjit, tendon rhadika. $22^{\text {nd }}$ edition. Haryana; Elsevier, 2011; pg.460

9. Murthy Srikantha K R. Illustrated Shushruta Samhita. Varanasi: Chaukhamba Orientalia;2010.

10. Murthy Srikantha K/R. Illustrated Shushruta Samhita. Varanasi: Chaukhamba Orientalia;2010.

11. Naryan J Vidwansa. A textbook of ayurvedic ophthalmology. shalakya $; 4^{\text {th }}$ edition Pune ; Vimal vision publication, 2015

12. Ajoy Viswam et al. Ayurvedic management of vatahata vartma (ptosis): A case study. Int. J. Res. Ayurveda Pharm. 2017;8(6):79-81 http://dx.doi.org/10.7897/2277-4343.086297 